\title{
Characteristics of cement pastes incorporating different amounts of waste cellular concrete powder
}

Монамmed ABED - Department of Construction Materials and Technologies Budapest University of Technology and Economics, Hungary - abed.mohammed@epito.bme.hu

RITA NEMES - Department of Construction Materials and Technologies Budapest University of Technology and Economics, Hungary=nemes.rita@epito.bme.hu

Érkezett: 2018. 06. 01. - Received: 01. 06. 2018. - https://doi.org/10.14382/epitoanyag-jsbcm.2018.28

\begin{abstract}
In this study, different amounts of waste cellular concrete powder (WCCP) as replacement of cement have been investigated as an attempt to produce green binder, which is useful for sustainable construction applications. In previous studies for the authors, the compressive strength increased when very fine WCCP was added as a filler material to the concrete. In the present study, the cement has been replaced by different amounts of WCCP where the replacement has been conducted from zero to up to $60 \%$ of cement mass. Consistency, compressive strength, bending strength and the activity index of WCCP through seven to ninety days specimens' age have been examined. The optimum WCCP replacement was up to $30 \%$, depending on which the activity index still increased to the end of the test period ( 90 days), and this could be an evidence for its continuity to increase for the longer ages. Despite replacing cement to up to $30 \%$ by WCCP increased the bending strength to be higher than the control one; it does the opposite for compressive strength. The main point in the present study is that there is a possibility of replacing cement by $30 \%$ of WCCP; however, it is preferable to be less than this amount.

Keywords: cellular concrete powder (WCCP), supplementary cementitious material (SCM), activity index, mechanical properties, waste material.

Kulcsszavak: pórusbeton por (WCCP) cementkiegészítố anyag (SCM), aktivitási index, mechanikai jellemzốk, cementpép, hulladékok.
\end{abstract}

\section{Introduction}

Concrete is the second highest used material in our plant after fresh water, and one of the most widely used construction materials; due to its durability, recycling potential, large range of performance and low materials cost, whereas the construction industry is one of the most industries that contribute to increased carbon emissions, especially production of Portland cement, which is the major source for the strength of concrete and the most expensive component as well, it is mandatory to minimize environmental impact and carbon footprint by incorporating the use of wastes materials as SCM in building construction. That is will be considered as a sustainable solution for enhancing the properties of concrete, decreasing the environmental impact of cement production and will also contribute to sustainable concrete [1-7].

Last decades witnessing discovering a big number of materials that prove its efficiency to use as supplementary materials for cement, where mainly used to improve the hydration of cement due to their physical characteristics and chemical compositions [8], but some of them full waste materials and also have the ability to improve various properties of concrete, which make them a suitable alternative of the traditional SCM $[1,9]$. One of these waste materials is waste cellular concrete powder (WCCP) which exists as one of the modern alternatives of these materials. WCCP has the same chemical composition as concrete, and fine powder has become as a by-product when the masonry elements are manufactured [10].
In the previous study [11], which studied the effect of some waste materials that used as non-hydraulic supplementary materials on the compressive strength and durability of C25/30 concrete, WCCP was one of these waste materials, which proved its ability to increase the compressive strength and enhance the durability performance of concrete based on the freeze test. One of the main conclusions was that it could enhance the performance of concrete by the using up to $10 \%$ replacement of very fine WCCP, which is the result of the cutting of cellular concrete blocks, where it has minimal cost and it does not require any preparation or pulverization before mixing. However, the optimal dosage of cellular concrete powder still requires further investigation.

As a continue for the previous study, another attempt has been investigated to introduce the application of very fine WCCP as a supplementary material, aiming to increase the durability of normal strength concrete [9]. The main finding of this study is that a given amount of WCCP could increase the strength and durability of concrete however, too much of amount of WCCP could cause detrimental effects, especially in compressive strength. The correct amount of WCCP can have a better performance than metakaolin on the durability of concrete, despite that metakaolin increases the compressive strength more than WCCP. WCCP is a completely a waste raw material and it is not need any production and preparation process, which means a significant decrease in cost and in $\mathrm{CO}_{2}$ emission as well. 
According to the literature, the incorporating of WCCP in concrete is not discussed enough especially the part of activation behaviour of the binder itself with time. The present study investigated the effect of incorporation of different replacement amount WCCP on the binder paste. Which is through pozzolanic reactions an additional hydration products could be formed by using SCM, where the expected results of these process are: increase strength, decrease in permeability and improvement of other durability properties [12]. Thus the physical, fresh and hardened properties have been tested in different ages aiming to determine the maximum replacement amount could be applied for concrete mixtures.

\section{Experimental work}

This experimental work was examined as an initial phase to $\mathrm{PhD}$ work for producing green self-compacting high performance concrete (GSCHPC) using different waste materials and recycled concrete aggregate, one of these waste materials is WCCP. Whereas the response of mortar systems and concrete systems depend greatly on the properties of paste materials especially in case of self-compacting concrete $[13,14]$.

\subsection{Materials}

The performance of seven groups of paste mixtures with replacement amounts $(0,10,20,30,40,50$, and $60 \%$ by mass) of cement by WCCP were examined with a w/b ratio of 0.35 , where the finding of optimum dosage and substitution ratio is very important because the application of SCM over the optimum amount may reduce performance both in strength and durability parameters [12]. A plain cement paste without the addition of WCCP was prepared at the same $\mathrm{w} / \mathrm{b}$ ratio as a reference. The composition of mixtures shown in Table 1. Paste mixtures were tested for their fresh and mechanical properties including consistency and compressive strength. The cement used throughout the experimental program was CEM I 42.5 $\mathrm{N}$ that complies with the requirements of EN 197-1:2000 to eliminate the effect of mineral admixtures on the test [15], however the WCCP used in this experimental work was a factory waste material that was collected from factory for cutting cellular concrete masonry in Hungary. The sieve curves for both WCCP and cement is shown in Fig. 1, which shows the large particles of WCC comparing to the cement.

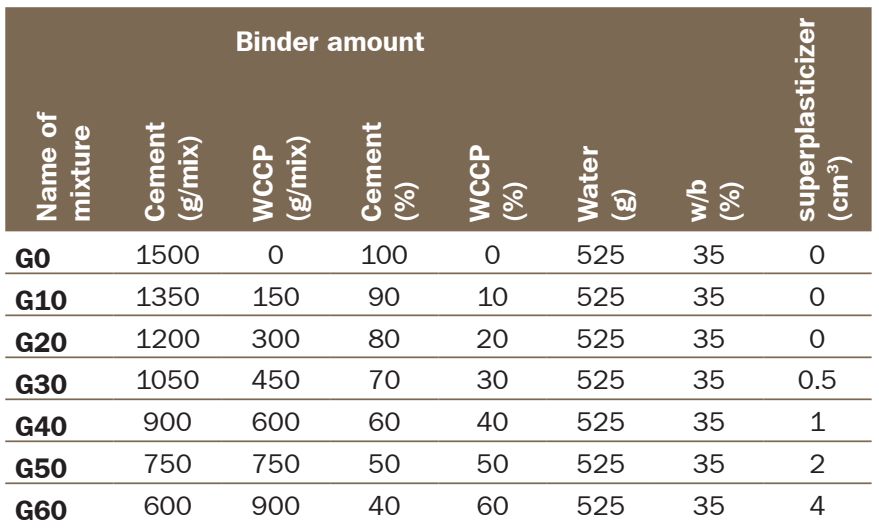

Table 1. Mixture proportions of cement pastes

1. táblázat A cementpépek összetétele

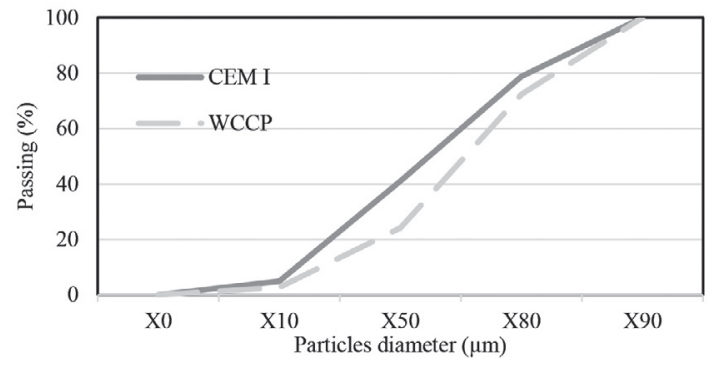

Fig. 1. Grading curves of cement and WCCP

1. ábra A cement és a pórusbeton por lézergranulometriás szemmegoszlása

The mixing water used for the reference was tap water that complies with the requirements of EN 1008:2002 [16]. To achieve the same flow-ability for the mixtures and produce a workable paste with the same $\mathrm{w} / \mathrm{b}$ ratio, a considerable amount of high range water reducing admixture (HRWRA) "Sika ViscoCrete-5 Neu" has been used in the present study. This type of admixtures reduces the water dosage of a concrete mixture for the desired slump class.

\subsection{Mixing and method}

Mixing was carried out in accordance with EN 196-1 [17], for a total mixing time of four and a half minutes partitioned in three stages, using a KM250 Kenwood Chef Major mixer, between each stage the mixture manually homogenized to achieve the highest homogeneity. The pastes were casted and compacted to produce two kinds of specimens: cubes $(40 \times 40 \mathrm{~mm})$ and prisms $(160 \times 40 \times 40 \mathrm{~mm})$, which vibrated using a vibrating table, to make nine cubes and nine prisms paste specimen for each mixture type. Casted specimens were covered with plastic sheets and placed in temperature room $\left(20 \pm 2{ }^{\circ} \mathrm{C}\right)$ for 24 hours until de-molding. Thereafter, specimens were cured for 7, 28, and 90 days by wrapping them using cling film. 18 samples in each group were tested; average values are reported. A total of 126 samples were prepared (6 samples $\times 3$ ages $\times 7$ mixtures). The consistency of fresh mixtures was obtained using the flow table, then for each testing age the bending and compressive strength have been examined.

\section{Results and discussion}

\subsection{Consistency}

Rheological behavior of fresh cement paste, mortar, and concrete is a key characteristic since it determines workability of the materials and greatly influence the final characteristics of the hardened properties [18]. For achieving the same range of flow-ability for all the groups of pastes it was necessary to use superplasticizer, whereas the workability decreased with increasing the WCCP amount, moreover decreased significantly when a high amount of WCCP. In the beginning, the flow-ability for G0 was determined and recorded $235 \mathrm{~mm}$, then for other mixtures superplasticizer added to achieve flowability in the same range (+/-5\%) of the reference mixture. The reduction in flow-ability may be due to the high surface area and the availability of WCCP to absorb a high amount of water, which absorbs hydration water resulting in less workability. Fig. 2 shows the increasing of superplasticizer demand with 
increasing WCCP amount as a result of decreasing the flowability for the same $w / b$ ratio.

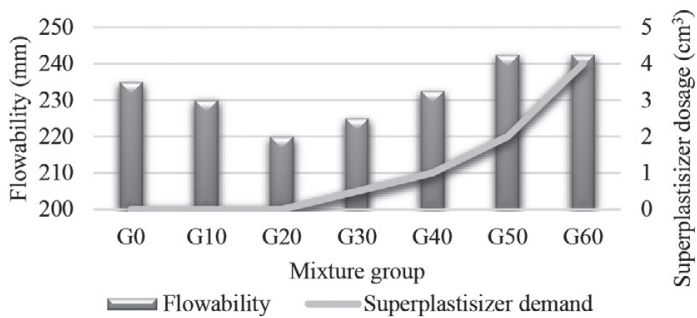

Fig. 2. Impact of WCCP on flow-ability \& superplasticizer dosage 2. ábra Apórusbeton por hatása terülésre és a folyósitószer-igényre

\subsection{Density}

The density has been measured for all specimens during different ages and the average values reported in Fig. 3, which is illustrated the decreasing of density by increasing the dosage of WCCP. It goes without reason that the density will decrease by increasing the amount of WCCP due to its lower density comparing to cement. Where depending on the density values it could be produced lightweight concrete by incorporating WCCP.

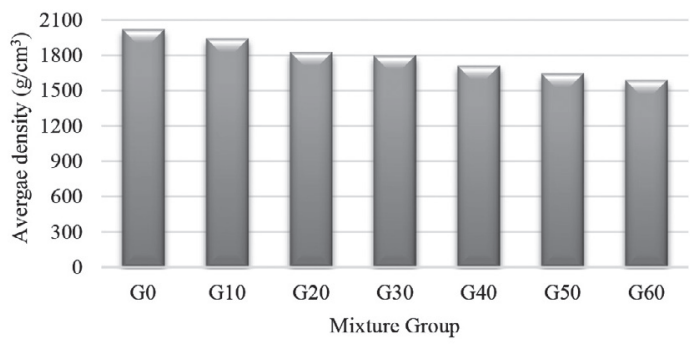

Fig. 3. Impact of WCCP on average density

3. ábra A pórusbeton por hatása a testsürüségre

\subsection{Compressive strength}

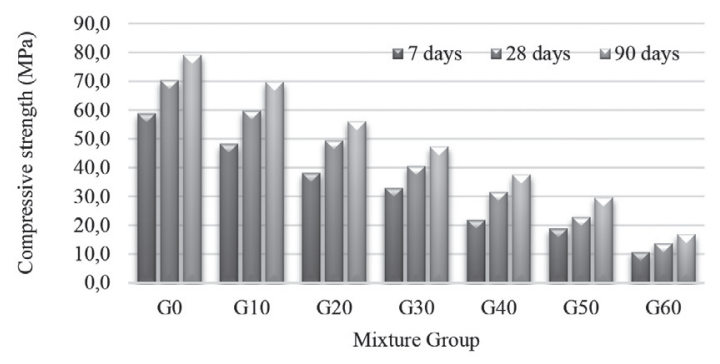

Fig. 4. Impact of WCCP on compressive strength

4. ábra A pórusbeton por adagolás hatása a nyomószilárdságra

Fig. 4 presents the compressive strength of the paste mixes at 7,28 and 90 days the compressive strength generally decreased when WCCP was included, and the greatest compressive strength was achieved for the paste mix with $0 \%$ WCCP. The compressive strength decreased linearly with increasing the amount of WCCP replacement. Nevertheless, the increasing of strength with time for the paste groups incorporated WCCP is higher than reference one up to $30 \%$ replacement by WCCP, which is an indication for the possibility of increasing the longterm compressive strength for pastes incorporating up to $30 \%$ of WCCP to be higher than the reference.

\subsection{Bending strength}

Incorporating WCCP up to $30 \%$ shows enhancing in the bending strength of cement paste, the increasing of bending strength with time for the paste groups incorporated WCCP is indicated to the low w/b ratio and the ability of WCCP for filling the pours which is enhance the bending strength, and also due to the low strength of paste itself. Fig. 5 presents the bending strength of the paste mixes at 7, 28, and 90 days.

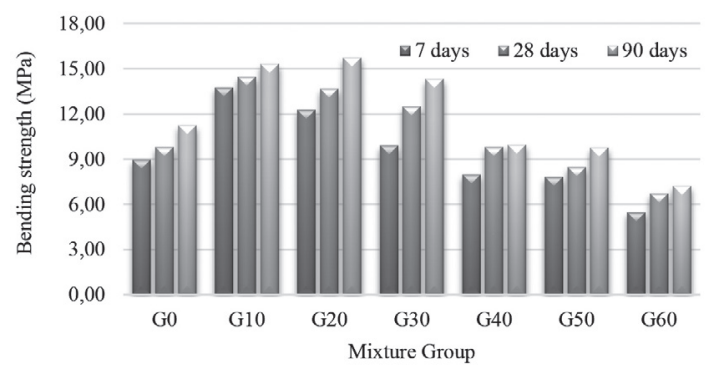

Fig. 5. Impact of WCCP on bending strength

5. ábra A pórusbeton por adagolás hatása a hajlitó-húzószilárdságra

\subsection{Activity index}

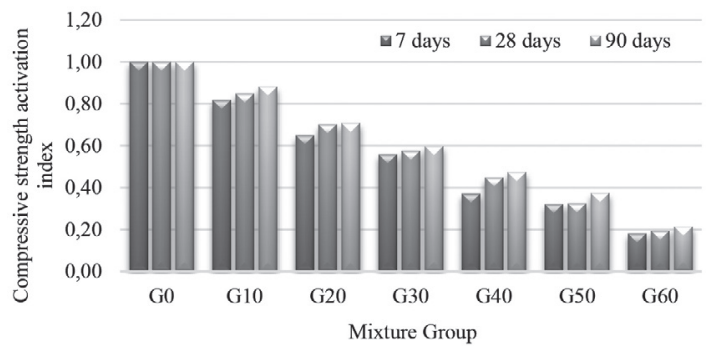

Fig. 6. Impact of WCCP on compressive strength activation index

6. ábra A pórusbeton por adagolás hatása az aktivitási index értékére nyomás esetén

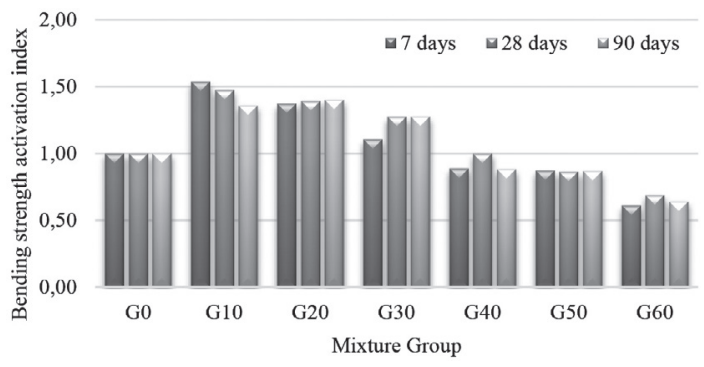

Fig. 7. Impact of WCCP on bending strength activation index

7. ábra A pórusbeton por adagolás hatása a aktivitási index értékére hajlitás esetén

Activity index is expressed by the ratio of both compressive and bending strength of cement paste mixture containing SCM replacement and strength of reference mixture with just cement, and it is express the hydration rate of the SCM [19]. The activity indices are presented in Fig. 6 and Fig. 7 for all mixtures groups in different ages. It shows that with increasing the age of specimens incorporating WCCP the activity index increase, thus the main reason for getting higher compressive and bending strength for WCCP specimens. It is clear that the most valuable replacement of cement by WCCP is up to $30 \%$ where the activity index increased up to 90 days. It is clear the positive effect of increasing WCCP replacement up 30\% in the activity index since the activity index increase with age. 
Whereas the behavior of activation for the pastes with more than 30\% WCCP shows optimum activation index after 28 and the start to decrease.

\section{Conclusions}

Using unprocessed WCCP as a replacement of cement for specific amount will not just decrease the cement consumption and its energy needed for production, but also will eliminate a series of costly and energy consuming mechanical and physical applications generated to treat other supplementary cementitious materials (SCM). Based on the results of this paper for replacing cement by WCCP up to $60 \%$ by mass for different aged up to 90 days have been conducted and the following conclusion could be drawn:

- The density and consistency of paste decreased with increasing WCCP dosage while increasing the WCCP dosage by more than $60 \%$ significantly made worse consistency.

- The compressive strength at 7,28, and 90 days decreased when WCCP included.

- The bending strength at 7, 28, and 90, days increased when WCCP included as a replacement of cement amount up to $30 \%$.

- Moreover, the activity index for both compressive and bending strength values still increased up to 90 days when up to $30 \%$ of WCCP used, which indicate for higher strength for long ages. However, the activation behavior is changing when the WCCP dosage being more than $30 \%$, where the relationship between the activation index and age turn from direct proportion to inverse proportion.

- In case of $40 \%$ or higher replacement, the long-time strength is unfavorable. The activation after 90 days was lower than the activation at 28 days of age.

- Although the present study justified using WCCP up to $30 \%$ replacement of cement amount, it should be less than this amount since the commonly used SCM amount is from $10 \%$ to $20 \%$.

- WCCP used in the present study effect the compressive strength negatively in the short-term results due to its coarse particles.

These conclusions are calling for farther detailed investigation research to produce green self-compacting high performance concrete while using different waste materials and recycled concrete aggregate.

\section{Acknowledgments}

Authors are grateful to the Hungarian Scientific Research Fund (OTKA) for the financial support of the OTKA K 109233 research project. Special thanks to Duna-Dráva Cement Kft., SIKA Hungária Kft. for providing the materials used in the experiments.

\section{References}

[1] Abed, M. - Nemes, R. (2017): Possibility of Producing Green, SelfCompactin, High Performance Concrete (GSCHPC) - Review. Concrete Structures, 2017. 18: p. 21-29.
[2] Aydin, E. - Arel, H. Ş. (2017): Characterization of high-volume fly-ash cement pastes for sustainable construction applications. Construction and Building Materials, 2017. 157: p. 96-107. https://doi.org/10.1016/j.conbuildmat.2017.09.089

[3] Mueller, H. S. (2017): Design, Material Properties and Structural Performance of Sustainable Concrete. Procedia Engineering, 2017. 171: p. 22-32. https://doi.org/10.1016/j.proeng.2017.01.306

[4] Dolado, J. S. - van Breugel, K. (2011): Recent advances in modeling for cementitious materials. Cement and Concrete Research, 2011. 41(7): p. 711-726. https://doi.org/10.1016/j.cemconres.2011.03.014

[5] Borosnyói, A. - Szijártó, A. (2015): Metakaolin vizsgálata cement kiegészítő anyagként a k-érték elve szerint, Épitőanyag - Journal of Silicate Based and Composite Materials, Vol. 68, No. 2, pp. 40-44. https://doi.org/10.14382/epitoanyag-jsbcm.2016.7

[6] Borosnyói, A. (2015): Development of compressive strength of HPC with the use of supplementary cementing material (SCM) combination, Épitöanyag - Journal of Silicate Based and Composite Materials, Vol. 67, No. 3, pp. 110-115. https://doi.org/10.14382/epitoanyag-jsbcm.2015.18

[7] Nemes, R. - Török, B. (2014): Bond of steel reinforcement in different lightweight aggregate concretes, Épitöanyag - Journal of Silicate Based and Composite Materials, Vol. 66, No. 2, pp. 7-12. https://doi.org/10.14382/epitoanyag-jsbcm.2014.2

[8] El Mir, A. - Nehme, S. G. (2017): Long term mechanical properties of self-compacting concrete made with slag cement and supplementary cementitious materials, Épitöanyag - Journal of Silicate Based and Composite Materials, Vol. 69, No. 2, pp. 59-65.

https://doi.org/10.14382/epitoanyag-jsbcm.2017.11

[9] Nehme, S. G. (2015): Infuence of supplementary cemneting materials on conventionel and self compacting concrete Part 1. -Literature review. Épitöanyag - Journal of Silicate Based and Composite Materials, 2015. 67: p. 28-33. https://doi.org/10.14382/epitoanyag-jsbcm.2015.6

[10] Gyurkó, Z. (2017): Effect Of Cellular Concrete Powder On Durability Of Normal Strength Concrete, Proceeding 12th Central European Congress on Concrete Engineering 2017, Tokaj p. 179-186.

[11] Gyurkó, Z. - Szijártó, A. - Nemes, R. (2017): Increasing freeze-thaw resistance of concrete by additions of powdered cellular concrete and clay bricks. International Conference on Analytical Models and New Concepts in Concrete and Masonry Structures AMCM. 2017, Procedia Engineering p. 11-18. https://doi.org/10.1016/j.proeng.2017.06.180

[12] Mlinárik, L. - Kopecskó, K. - Borosnyói, A. (2016): Properties of cement mortars in fresh and hardened condition influenced by combined application of SCMs, Épitöanyag - Journal of Silicate Based and Composite Materials, Vol. 68, No. 2, pp. 62-65. https://doi.org/10.14382/epitoanyag-jsbcm.2016.11

[13] Rizwan, S. A. - Bier, T. A. (2008): Self-Compacting Paste Systems using Secondary Raw Materials. Pakistan Journal of Engineering \& Applied Sciences, 2008. 3: p. 1-7.

[14] Rizwan, S. A. - Latif, W. - Bier, T. A. (2016): Response of self-consolidating cement paste systems containing Acacia Nilotica Gum as an organic admixture. Construction and Building Materials, 2016. 126: p. 768-776. https://doi.org/10.1016/j.conbuildmat.2016.09.097

[15] EN 197-1: Cement - Part 1: Composition, specifications and conformity criteria for common cements 2000 .

[16] EN 1008: Mixing water for concrete-Specification for sampling, testing and assessing the suitability of water, including water recovered from processes in the concrete industry, as mixing water for concrete 2002.

[17] EN 196-1: Methods of testing cement. Determination of strength. 2016.

[18] Kara, P. (2015): Performance of lamp glass waste powder (LGWP) as supplementary cementitious material (SCM) - viscosity and electrical conductivity, Épitöanyag Journal of Silicate Based and Composite Materials, Vol. 67, No. 1, pp. 12-18. https://doi.org/10.14382/epitoanyag-jsbcm.2015.3

[19] Mucsi, G. - Csőke, B. (2012): Power Plant Fly Ash as a Valuable Raw Material. Geosciences and Engineering, 2012. 1(1): p. 223-236.

Ref.:

Abed, Mohammed - Nemes, Rita: Characteristics of cement pastes incorporating different amounts of waste cellular concrete powder Építőanyag - Journal of Silicate Based and Composite Materials, Vol. 70, No. 5 (2018), 151-154. p. https://doi.org/10.14382/epitoanyag-jsbcm.2018.28 